\title{
A Preliminary Study on the Training Mode of Student's Soft Power for
}

\section{Employment in Higher Vocational Institute}

\author{
Zhaochu Qian ${ }^{1, a}$ \\ ${ }^{1}$ Chongqing Business Vocational College, Chongqing, 400036 \\ a email
}

Key words: students in higher vocational institute; soft power in employment; training mode; a preliminary study

\begin{abstract}
Along with the increasing pressure of employment born by students in higher vocational institute, a hot topic in education goes to how to strengthen the practice ability and professional skill training of students, as well as improving students' soft power, in vocational colleges. From the angles of ideological and political education and how to build graduates' brand in employment, this paper makes certain discussion on the problems of how to improve the students' soft power in employment and the training modes according to the characteristics of higher vocational education.
\end{abstract}

\section{Introduction}

With the rapid development of economy and technology in our country, higher vocational institute quickly realized the expansion in scale. By the end of 2008, higher vocational institutes in our country had surpassed more than 1200, which account for about $70 \%$ of the total number of national universities in our country. Then, internal students in higher vocational institutes surpassed 13 million and they accounted for more than half of all the students in colleges and universities of higher learning in our country. "Let the unemployed have jobs and let the employed happy" and "Make a living for ourselves and serve the mass" are the goals proposed by Mr. Huang Yanpei, a pioneer of vocational education in our country. However, it is no doubt that the situation of employment for the graduates of higher vocational institutes. Therefore, how to improve the soft power of students in higher vocational institutes has become a new topic for us.

The concept of soft power was proposed by Joseph S. Nye in 1990 and the issue on the construction of college's students' soft power was paid attention to. It is clearly noted in the "Several Suggestions on the All-round Improvement of Teaching Quality in Higher Vocational Education” carried out by the Ministry of Education that "higher vocational institutes should take into account students' characteristics so as to cultivate the students' social adaptability, educate them to form the concept of life-long study, improve their ability to learn, and teach them with the abilities of communication and teamwork before improving the students' practical ability, creative ability, employment ability and entrepreneurial ability and cultivating them into socialist builders and successors with the all-round development of morality, intelligence physique and aesthetic.” In fact, this is the best explanation for the cultivation of student's soft power. From the angles of ideological and political education, how to realize the seamless connection in the cooperation in school running between universities and enterprises, and how to build up graduates' brand in employment, this paper makes certain discussion on the problems of how to improve the students' soft power in employment and the training modes according to the characteristics of higher 
vocational education.

\section{Ideological and Political work: diversified education in career planning}

It is determined by the characteristics of school running and training objective owned by higher vocational colleges and other general universities of higher learning that we should treat the work of students' career planning in higher vocational institutes as a whole-course work. The counselors should make thorough investigation for the students from the new students' entering into university and establish electronic record for the students including students' learning ability, personality, temperament type, and family background, etc; through individual conversations and quality evaluation, we'd put forward specific advice on career planning for each student and help students establish training objectives on employment ability; then, cultivate the students' employment ability through targeted courses, vocational guidance, quality promotion, and social practice, etc; in different stages of learning, carry out quality assessment of employment ability for students, make timely communication with the students to feedback information on assessment, correct and improve continuously their personal career goals, so as to determine the development direction upon graduation; carry out post training, so as to cultivate students' spirit of dedication and entrepreneurship, guide the graduates in entering into the workplace, and achieve the zero distance between students and certain profession.

It is determined by the characteristics of higher vocational colleges itself and the characteristics of its students that students' psychological problems in higher vocational institutes should be timely settled. First of all, the orientation of higher vocational institutes is tailored for vocational education, which has certain difference with the general idea held by the traditional society. Therefore, when the students were admitted to higher vocational colleges, they may have the negative psychology of "being inferior" and are easy to feel inferior. Secondly, in terms of the source of students, most of the students in higher vocational institutes failed the entrance examination for primarily undergraduate and they have relatively lower level in knowledge. Because they failed to receive good education in childhood, they have big defect in ideological understanding, many students are not interested in theoretical knowledge learning, they are unwilling to learn, and are incapable of learning; moreover, because students are always in the school to learn certain knowledge, they are not close enough with the society and their psychological age is not as older as it should be. As they are not so proficient with the society and career, psychological hazard exist in employment psychology.

As employment situation is very grim for university students nowadays, it is necessary for the students to know how to design their career and how to cultivate the ability for certain career or job, so as to meet their demands of employment and promote key competitiveness for certain profession.

We always give students the example: if a company comes to our school to recruit its personnel, we'd think about a question — as we students almost have the same theoretical and professional skill, what is your trump card in competing with them? This question has close relationship with key competitiveness. Almost all the students in the school have the same courses and similar basic skills, so how to cultivate a professional ability, your magic weapon in competition, which can distinguish yourself from others? It is required that the counselors should guide the students to cultivate their own key competitiveness after careful analysis on the students according to the characteristics of different students. That is to say, we'd find a hobby related to our profession besides the courses prescribed in school. After several years' cultivation, we'd nurture it into our advantage and then the key competitiveness in our profession.

The growth of talent is long-term, and so does the improvement of the "soft power". As a leader in 
students' career planning, counselors should take care of the students from all aspects and guide them to absorb nutrition from study, life and social practice. As for the training of "soft power", it should be listed in the project of cultivating students' morality through effective way and effective quantitative assessment should also be carried out.

Therefore, during the three years' learning process in college, counselors should effectively carry out training modes which focuses on students' inner virtue cultivation. For instance, we'd regularly organize simulated recruitment, so as to promote students' ability in application and interview; we'd hold lectures or trainings on interpersonal skills, social etiquette and image design, etc,; we'd carry out the impromptu speech which requires the whole class' participation, so as to exercise the students' ability in oral expression; we'd organize the outdoor training so as to cultivate the students spirit of the bearing hardships and the ability of teamwork, cooperation and resilience; encourage students to participate in activities on quality promotion, such as driving, mandarin speaking and Chinese culture, so as to improve one's comprehensive quality. And all of these should be included in the evaluation of moral education as an important index of assessment, so as to promote students' soft power in employment in the form of institutionalization.

\section{The training of university-enterprise cooperation: to establish a seamless docking mechanism}

The demands of our society vary along with the advancement of science and technology with the passage of time. In major setting-up, higher vocational institutes should know the market well and make exquisite judgment for demand of the future market through university-enterprise, so as to timely understand the demand of the current market and the future market. Thus, the scheme for major setting-up and cultivation can be co-designed by the enterprise, professional organizations, colleges and education departments, and it can be constantly revised according to the changes in labor market. Then in the construction of curriculum system and teaching knowledge, theoretical knowledge is enough as long as it is sufficient in usage. In the teaching process, we'd focus on the cultivation of practical skills according to the characteristics of regional economy. Through the investigation and analysis, we'd know the comprehensive ability that is in high demand for specific profession, so as to conduct effective cultivation for such students.

On this basis, we can establish the mode of double-certificate education according to the employment demands. Thus, through the steps of teaching and exam, the tests for employees' professional ethics, professional quality evaluation and performance evaluation can be realized, so as to promote the combination of cultivation in vocational colleges and the actual requirements of enterprises. Then, the courses can be organized through tasks of actual work, working process and working situation, so as to standardize professional curriculum development, curriculum structure, teaching staff, teaching guidance, and the process of teaching activities analysis in the vocational institutes, forming a vocational curriculum system with the main body of task performing. Thus, after entering into the college, students from higher vocational institutes have the advantage of vocational ability etc. which are unable to be possessed by ordinary university students and they have due qualities and team spirit that should be mastered by the employees in the enterprise. Then, such ability will become soft power in employment in the future.

Only when vocational institutes at output end and enterprise at the input end are at the same pace in university-enterprise cooperation and they are close with each other, can the students cultivated by vocational institutes adapt to the positions of an enterprise and be welcomed by the enterprise. Only when seamless connection between the two is achieved, can the institute know about the enterprise's demand and organize teaching activities according to the requirements of enterprise, realizing the synchronous 
management between the university and the enterprise. Thus, the students can feel the enterprise atmosphere ahead of schedule, so as to enhance the ability to adapt to work.

Xunteng International for instance, they create the personnel training mode of "enterprization", and implement the whole-process teaching mode based on software development--the "system of station" of class and the "competition for projects" of teaching. There, teachers are "project managers" and students are employees. The classrooms are decorated by imitating the joint office area in enterprise and the students' seats are transformed into "stations" in an enterprise. Thus, the students and teachers feel that they are situated in a real enterprise-like teaching and development environment, which would promote students' employment competitiveness rapidly. This is the training environment created by Xunteng International for the students of software engineer.

Teachers, the essence for students' cultivation, refer to teacher on professional education and teacher on moral education respectively (counselor) and both of them are of vital importance in students training. In addition to basic conditions of teachers, "double-type" teachers should have the following two qualities: being the professional talent who can guide the students in realizing the institutes and the enterprises' complementing each other in teaching performed in the institute and skill training carried out in the enterprise; being the professional people who is the type of teacher that knows what type of person is needed in certain enterprise and can cultivate students' professional quality according to certain situation, and they can provide students with the ability of innovation and entrepreneurship in enterprise management and operation experience training. As a result, the institute should send their teachers to get trained in certain enterprise, so as to learn theories and skills that is related to the enterprise and create conditions vigorously to introduce industry elites to give speeches in the institutes. At the same time, encourage relevant departments and teachers to start a business or company, so as to offer a practical platform for teaching and scientific study.

With these conditions, the institute can establish relevant plans according to demands of the enterprise and teachers can teach by combining with their own experience. Thus, they would not be constrained to the provisions of the current teaching material and provide students with practical platform in teaching. Then they can offer vocational guidance to students and improve the students' comprehensive quality and creative ability. Therefore, the students would know well the management environment and operation mode in certain enterprise and they would have their own views before they take up their quarters, which would effectively achieve the docking between teaching in the institute and the enterprise's demands. Thus, the students would be the talents who not only have overall operational skills, but also know well the market and enterprise management of innovative talents. Then, they'd have a better potential for development.

\section{The creation of employment environment: support the students with famous brands}

If the students are products, enterprises are consumers. So how to create a core value chain between products and consumers should be paid attention to by us. In fact, it is about how to build a good reputation for the graduates. If we solve the problem of value chain well, we can provide the students with good employment environment. Actually, we'd offer soft power on employment for the students. Some people think that this has nothing to do with students' soft power in employment and I personally hold the view that although there is no direct relationship, they have close relationship. Generally speaking, the graduate who left school early provide support to the students who left late and the students who left late provide support to the students at school. As for the training mode of the institute, it is the relationship between the overall situation and the individual. Therefore, it should be highly concerned by 
us.

The word "public praise" refers to "it is used to describe verbal praise from the public" in Cihai. It is also widely regarded as the public's discussion and oral praising. So does the public praise obtained by the graduates--"excellent performances of senior fellow and sister apprentice are the great help to college students in school.” This is the suggestion from a senior expert on human resource. In fact, it is not the profound problem that is difficult to understand. If a lot of backbone employees are graduated from an institute in a company, the graduates of the institute have good public reputation in this company. Accordingly, if quantities of graduates from the same institute are proficient with their business with high professional quality and make great contribution to the development and strengthening of a company, reputation of the institute in the society is good. Then the society would have high recognition degree for graduates of the institute. The Private Chung-hsin High School in Taiwan is equivalent to vocational school in the mainland. Because of its graduates' excellent performance, the words "only hire the graduates from the Private Chung-hsin High School” can be seen in the advertisement published in major newspapers in Taiwan. This is resulted from the graduates' good reputation formed and such good reputation gradually become famous brands, which creates a good external employment environment for its graduates and become a kind of soft power for the students when they are employed.

\section{Acknowledgements}

This paper is the staged research result for Study on the Training Mode of Innovative Career-creating Talents in Colleges and Universities under the New Normal (project number: KJ1504301)

\section{References}

1. Dai Guojiang, On the Soft power of University Students in Employment, Journal of South China University of Technology (social science edition), 2007, 04

2. Zhu Xiongcai, Innovation of Evaluation Pattern for Students from Higher Vocational Institutes: the Employment Pattern of Trinity, China Higher Education Research, 2006, 12

3. Zhi Wenxuan, Discussion on the Employment Force Promotion of Higher Vocational Institute Students, BBS of Higher Education, June 2006, the $3^{\text {rd }}$ Issuance 